\title{
Referral program in the context of social capital and digital marketing methods
}

\author{
Anastasii I. Klimin \\ Institute of Industrial Management, \\ Economics and Trade, Graduate \\ School of Management and Business \\ Peter the Great Saint Petersburg \\ Polytechnic University \\ Saint Petersburg, Russian Federation \\ klimin@kafedrapik.ru \\ Rouhollah Abbaszadeh \\ Technical and Vocational university \\ (Shahid Chamran campus) \\ Kerman, Kerman province, Iran \\ rouhollah.abbaszadeh@gmail.com
}

\author{
Pavel S. Kozlovskii \\ Advanced Manufacturing Technologies \\ Center (National Technology \\ Initiative), Scientific laboratory of \\ Strategic development of engineering \\ markets \\ Peter the Great Saint Petersburg \\ Polytechnic University \\ Saint Petersburg, Russian Federation \\ pavelspb@mail.ru
}

\author{
Pavel A. Sataev \\ Institute of Industrial Management, \\ Economics and Trade, Graduate \\ School of Management and Business \\ Peter the Great Saint Petersburg \\ Polytechnic University \\ Saint Petersburg, Russian Federation \\ 13371281@kafedrapik.ru
}

\begin{abstract}
More and more indicators affecting the company's profits are becoming available for calculation due to the development of technology. Social capital can be one of these indicators. The study concludes that the referral program is the use of the external social capital of the enterprise. Digitalization allows companies to develop the interaction with consumers. There is a simplification and improvement of such marketing tools as loyalty programs, which are already moving into the field of digital marketing. Companies can enable customers to attract new customers for a certain reward using user-friendly web interfaces or applications. The objectives of the study are: to clarify the term "social capital"; to describe various concepts of attracting customers for sales growth, including digital marketing methods, in order to more accurately determine the referral program; to propose formulas for calculating the efficiency of the referral program.
\end{abstract}

Keywords-social capital, referral program, customer acquisition cost, referrer, digital marketing

\section{INTRODUCTION}

The relevance of the study of the term "social capital" is due to a wide variety of interpretations. It is necessary to highlight the key meaning and make a complete definition. "Social capital" is a complex concept. If we consider it in the context of the enterprise, it will include not only the relationship between employees of the organization.

There are various ways of attracting external resources for sales growth, it can be work with existing customers, the introduction of rewards for promoting the company's products or even a special business model. It is necessary to understand the various concepts and give an accurate description of the referral program. The referral program is the use of the external social capital of the enterprise; this can be proved by analyzing the key elements of social capital in relation to the principle of the referral program.

The development of such elements of digital marketing in the activities of the enterprise, such as Big Data, CRM systems, omnichannel customer interaction programs, tracking the digital consumer footprint, etc. allows companies to track and evaluate more and more indicators that affect profits. Social capital can be one of these indicators. It is necessary to analyze the use of the CAC (customer acquisition cost) in the context of savings from the implementation of the referral program.

\section{TERM "SOCIAL CAPITAL"}

Social "Social capital" includes the concept of "capital", which must be disassembled to compile a precise definition. This term is often explored by the author of various articles on the word capital (human, intellectual, social, etc.).

The following important interpretations can be distinguished:

- The capital of physiocrats and capital in the classical political economy - materials and supplies, and other means of production, as well as consumer goods for the labor force $[1,2,3]$.

- The capital in the fundamental study of Marx is the relationship between the capitalist (those who own the tools of labor) and hired workers [4]. Emphasis is placed on the self-expansion of capital in the process of circulation (M-C-M'). Money determines the cost of capital. K. Marx said that the consumption of labor is the reification of labor and the creation of value. K. Marx also defined capital as self-increasing value [5, 6].

- Neoclassical capital - costs (wealth [7]) that lead to abandoning consumption at a given moment in order to earn income in the future.

- Capital according to C. McConnell and S. Bru is equated with investment resources and again covers all means of production (machines, premises, transport, etc.) $[5,8]$.

The term "social capital" has a large number of formulations. The founder of social capital, P. Bourdieu, defines it as resources related to the possession of strong ties or relationships, acquaintances, group membership, which provides each of its members with collective capital support [9]. 
J. Coleman (also one of the key sociologists who dealt with this term) supplemented the notion of "social capital" with "trust receipts" that appear in the process of relationships between individuals and which can be returned in the form of response actions. Trust receipts are liabilities arising in response to efficiencies.

The purpose of studying this term can serve:

- the ability to use social capital in the activities of the enterprise and evaluate it;

- develop a common terminology and highlight similar concepts;

- separately organize activities aimed at improving this indicator;

- engage in company valuation, along with intangible assets.

The question of the concept of "social capital" is considered by V.A. Rudyakov in the monograph "The adaptive efficiency of the company in a modern economy" [10]. The author divides the definitions used in the scientific environment into 3 groups:

- External type. For example, Bart R. says that social capital implies contacts with other people (with colleagues and friends). With the help of these contacts a person can use his financial and human capital [11].

- Internal type. For example, Maskel P. represents social capital in the framework of the system of values and beliefs that people share and use as a guide for the rules of behavior in everyday life [12]

- Mixed type. Schroeter S. Represents social capital as a set of relationships that minimize transaction costs [13].

Rudyakov V. A. calls social capital as the firm's connections, which are included in its economic relations system, and which facilitate access to resources from other economic actors (or help in using their resources) more effectively than without such connections.

Based on the analysis of a number of definitions from different researchers, three key features of the term "social capital" can be distinguished [14]:

- Social capital in the context of interpersonal relationships. These are contacts, social connections, social networks within society, etc. [15].

- Social capital in the context of a specific set of values. This includes trust, values, beliefs, processes that contribute to the development of the team, etc. $[12,16]$.

- Social capital as a resource, as the construction of relationships within society and the benefits of it. Resources that can be obtained from social structures; resources within social networks $[17,18]$.

Based on these theses, another definition of social capital can be presented. Social capital is a set of connections between people within a society (company, suppliers, etc.), built on the basis of established or developed values (trust, culture, etc.) that can ensure the implementation of certain tasks in the case of their mobilization and proper use (that can lead to income).
This definition is similar to the interpretation of Robert Putnam [19], according to which social capital is a network of relationships that exist between people, as well as the norms of these relationships and trust, that is, everything that gives participants of the relationship the opportunity to act more effectively to achieve common goals.

We can cite the following classification of social capital:

- Individual social capital. When we consider the relationship between people without reference to enterprises.

- Social capital of small groups. When we consider relationships within teams (for example, project ones).

- The social capital of the enterprise. When we consider the relationship between people in the context of the enterprise.

Social capital in the enterprise can be divided into:

- External. Refers to the relationship between the enterprise and the external environment (intermediaries, suppliers, customers).

- Internal. Refers to relationships within the company. This will include both individual social capital and social capital of small groups.

\section{THE CONCEPTS OF PROMOTION BY EXTERNAL SOURCES AND METHODS OF DIGITAL MARKETING}

Companies receive new opportunities for interaction with consumers with the development of technology. Companies are beginning to actively use not only internal social capital, but also external. The paper discusses such interactions that allow consumers to act as those who are looking for customers for the company. There are several such concepts:

\section{A. MLM (Multi-Level Marketing)}

Definition. MLM is a system in which an enterprise realizes the distribution of goods through a network of independent distributors (consultants) who also attract other people to distribute goods and services [20]. It is a concept for the sale of goods and services, which is based on the creation of a network of independent distributors, which are also called sales agents. In addition to product sales, the sales agent can also engage in attracting other sales agents. The income of the network participants is formed from sales (commissions) and additional reward, which depends on the volume of sales of involved sales agents.

The impact of technology on the model. Technologies simplify implementation and work with this concept. This is due to the development of electronic document management systems, databases, etc.

Key meaning for the company. MLM is a Business Model.

Why do referrers use? Additional income; earnings.

Examples. Among the main companies on the market are the following: Amway, Avon Products Inc., Herbalife, Vorwerk, Mary Kay, $\mathrm{Nu}$ Skin, Tupperware, Oriflame Cosmetics, Young Living, Jeunesse. 


\section{B. Affiliate marketing}

Definition. Affiliate marketing is a way to promote and sell products through work through independent sellers who realize promotion for a commission. In digital marketing, CPA marketing (CPA - cost per action) is a search for customers for some product, service, company, using various internet marketing tools. Its essence is very close to the referral program.

The impact of digital marketing technology on the model. A company needs to keep a record of sellers, see the binding of specific buyers to specific sellers, calculate the amount of reward, pay these rewards. At the moment a company can fully automate this process, using various information systems. Therefore, a number of companies operating in the field of e-commerce, implement this approach, inviting to the interaction sellers and Internet marketers (webmasters, traffic arbiters) who are not employees of the company.

Key meaning for the company. Attracting third-party vendors and marketers.

Why do referrers use? Additional income.

Examples. Travelpayouts is a travel service, with a strong focus on affiliate programs. Partners earn a commission for booking by referral link. The company identifies the following categories as partners: travel agencies, site owners, IT specialists, developers, traffic arbiters (the company has developed a list of permitted and prohibited activities), travelers, bloggers. Partners get access to a personal account similar to a classic advertising account. It includes various indicators: visitors, searches, clicks, revenue, CTR, CPC, etc.

\section{Referral program}

Definition. A referral program is a process of rewarding existing customers for attracting new ones [21].

The impact of digital marketing technology on the model. User Experience and User Interface are of great importance for the referral program. Companies can implement the referral program offline, using promotional codes, coupons and other things, but this will complicate the perception of the program for the client (referrer), that will lead to a decrease in its effectiveness. Therefore, now the majority of companies implementing referral programs use web interfaces and mobile applications where key indicators of the referrer are tracked and explicitly presented. sales.

Key meaning for the company. Marketing tool; increase in

Why do referrers use? Reward (bonuses).

Examples. The booking.com project has a program "refer a friend". The essence of the program is that the client (referrer) shares a referral link (paid promotion of links is prohibited) and receives bonuses for the use of the service by the person (referral) who made the purchase through the link. In this case, the bonus receives referrer and referral (in the form of discounts on reservations).

\section{THE MODEL OF CALCULATION OF POSSIBLE REWARD IN THE REFERRAL PROGRAMM}

It is necessary to analyze the referral system in terms of attracting customers:
- The company gives bonuses to the referrer, who attracts new customers for the company.

- The company gets access to the client's connections (his contacts, acquaintances, etc.), to people who have made a deal or followed the link.

- The company implements a referral program in order to attract new customers, thereby increasing profits.

- The process is repeated for referrals who may become referrers.

Referral program is the use of external social capital of the enterprise. To prove this, it is necessary to analyze the use of the term "social capital" in the context of a referral program.

- As mentioned earlier, social capital is a set of contacts. The company uses a set of customer's contacts in the referral program.

- These contacts are built on values. In the referral program, the value is represented as trust between referrals and the referrer or the benefit of participating in the referral program.

- Social capital leads to income. The purpose of the referral program is to increase profits for the enterprise.

It is important for companies to determine the benefits of implementing a referral program. This benefit may also be the size of the reward allocated to the referral system (if it is not included in the calculations) First of all, it is necessary to determine the CAC from the referral program. This is a technically challenging, but possible step, given the improved tracking of the digital consumer's footprint, the development of BI tools for analysis and customization of customer interactions. Then it is necessary to compare the CAC from ordinary marketing activities with the CAC from the referral program.

If pricing involves the inclusion of commissions for intermediaries (for example, this is typical of the real estate market, where the price includes agents' remuneration), then we can conclude that the amount of this commission will be savings from the referral system or the amount that can be allocated to referrers.

Further, the proposed actions will be presented in the form of formulas.

Calculating the CAC without taking into account the referral system will look like this (1):

$$
C A C_{T-R P}=\frac{M C-M C_{R P}}{Q-Q_{R P}}
$$

( $C A C_{T-R P}$ - customer acquisition cost excluding the referral system, currency unit/person; $M C$ - marketing costs, currency unit; $M C_{R P}$ - referral costs, currency unit; $Q$ number of customers, person; $Q_{R P}$ - number of referrals in the system, those who made a deal at the expense of the referral system, person).

The external social capital of the enterprise (revenue from referrers) is calculated as follows (2):

$$
R P_{T}=\sum_{i=1}^{\infty} R_{i}
$$


$\left(R P_{T}\right.$ - the total value of external social capital in the referral program, currency unit; $R_{i}$ - revenue from the i-th referral, currency unit).

Savings from using referral program in terms of attraction costs (RRP) (3):

$$
R R P=\left(C A C_{T-R P}-C A C_{R P}\right) * Q_{R P}
$$

( $C A C_{R P}$ - customer acquisition cost in the referral program, currency unit).

Then the amount of reward to referrers is calculated by adding a step-up or step-down coefficient (4):

$$
C R P_{1}=C_{1} * R R P
$$

$\left(C R P_{1}\right.$ - amount of funds allocated to the referral system (as rewards and discounts), currency unit; $C_{1}$ - the percentage that the company is ready to allocate to the referral program, $\%)$.

If in pricing there is a fee to intermediaries, the amount of reward will be calculated as the amount of reward due to the decrease in the CAC plus the percentage allocated to intermediaries in pricing (5):

$$
C R P_{2}=C R P_{1}+\left(C_{2} * R P_{T}\right)
$$

$\left(C R P_{2}\right.$ - the amount of funds allocated to the referral system (as rewards and discounts), taking into account the mediator in pricing, currency unit; $C_{2}$ - the percentage of the average check that a company can allocate to the referral system, \%).

The model was developed as part of the elaboration of the hypothesis on the implementation of the referral system in the hotel complex. At the moment it is in the approbation stage, therefore it is provided without actual statistical data.

\section{CONCLUSION}

A study of the terminological component of "social capital" was conducted and its classification was compiled. Social capital includes the following elements:

- A set of connections between people

- built on the basis of established values

- that will lead to income (for the company).

The differences between MLM, affiliate marketing (CPA marketing), referral program, as a digital marketing tool are highlighted.

The connection of the referral program and the external social capital of the enterprise has been analyzed.

A model to calculate savings from the introduction of a referral program or the amount of reward that can be provided to referrers was presented.

\section{REFERENCES}

[1] A. Mokronosov, Yu. Krutin "Human capital or human potential”, Ideas and Ideals № 2 (32), t. 2. 2017 (in Russian).

[2] M. Blaug, Economic Theory in Retrospect, Cambridge University Press; 5 edition (March 28, 1997).

[3] Classics of Economic Thought: Compositions V. Petty, A. Smith, D. Ricardo, J.M. Keynes, M. Friedman. - M .: Eksmo-Press, 2000. - 896 $\mathrm{p}$ (in Russian)

[4] K. Marx, F. Engels. Works. V. 25, Part 2. - Ed. 2nd - M .: Gospolitizdat, 1962. - p. 552 (in Russian).

[5] S. Shtrtbul, "Social capital: on the issue of conceptualization of the term", Omsk Scientific Herald. Publisher: Omsk State Technical University. - 2009. -№6 (82). p. 89-92 (in Russian).

[6] The course of political economy. ed. N.A. Tsagolova. - M .: Economy. - 1973. - T. 1. - p. 196 (in Russian).

[7] A. Marshall, Principles of political economy. - M .: Direct Media, 2012. - p. 2126 (in Russian)

[8] K. McConnell, S. Brue. Economics: principles, problems and policies. - M .: Republic. - 1992. - T. 1. - p. 37 (in Russian).

[9] P. Bourdieu Capital Forms // Economic Sociology. 2005. №3. p. 60-74 (in Russian).

[10] V. Rudyakov, "The adaptive efficiency of a firm in the modern economy", V.A. Rudyakov. - Irkutsk: BSUEP Publishing House, 2009. p. 196 (in Russian)

[11] R. Burt, Structural Holes: The Social Structure of Competition. Cambridge (Mass.), 1992. p. 311p.

[12] P. Maskell, Social Capital. Innovation and Competitiveness, Social Capital. Critical Perspectives. Eds. S. Baron, J. Field, T. Schuller. Oxford: Oxford University Press, 2000. - p.111-123.

[13] S. Szreter, Social Capital, the Economy, and Education in Historical Perspective// Social Capital. Critical Perspectives /Eds. S. Baron, J. Field, T. Schuler. - Oxford: Oxford University Press, 2000. - p. 56-77.

[14] A. Klimin, P. Kozlovsky, P. Sataev, "Directions of the Formation and Development of Social Capital in the Context of Holistic Marketing", week science SPbPU, Proceedings of a scientific conference with international participation, 2018. p. 372 - 375 (in Russian).

[15] P. Bourdieu. Social space and the genesis of "classes" / Bourdieu P. Sociology of politics. - M .: Socio - Logos, 1993. - p. 55-97 (in Russian).

[16] Ilin, I. V., Izotov, A. V., Shirokova, S. V., Rostova, O. V., \& Levina, A. I. (2017). Method of decision making support for it market analysis. Paper presented at the Proceedings of 2017 20th IEEE International Conference on Soft Computing and Measurements, SCM 2017, 812814

[17] J. Nachapiet, S. Ghoshal, "Social Capital, Intellectual Capital, and the Organization Advantage”, Academy of Management Review. - 1998. - vol.23.

[18] I.V. Ilin, O.Y. Iliashenko, A.I. Klimin, K.M. Makov. Big data processing in Russian transport industry (2018) Proceedings of the 31st International Business Information Management Association Conference, IBIMA 2018, pp. 1967-1971.

[19] R. Putnam, Bowling Alone: The Collapse and Revival of American Community. - New York, 2000. p. 133.

[20] D. Sokolova, "Taxation problems in network marketing", Intellectual potential of the XXI century: steps of knowledge. Publisher: Limited Liability Company "Center for the Development of Scientific Cooperation”, 2010. №1. p. 316-320 (in Russian).

[21] P. Schmitt, B. Skiera, Christoph Van den Bulte, "Referral Programs and Customer", Value Journal of Marketing, Vol. 75, Issue 1, p. 46-59. January 2011 